\title{
A groundwater-fed coastal inlet as habitat for the Caribbean queen conch Lobatus gigas - an acoustic telemetry and space use analysis
}

\author{
Thomas C. Stieglitz ${ }^{1,2,4}{ }^{*}$, Antoine M. Dujon ${ }^{2,3}$ \\ ${ }^{1}$ Centre for Tropical Water \& Aquatic Ecosystem Research and School of Engineering \& Physical Sciences, \\ James Cook University, Townsville, QLD 4811, Australia \\ ${ }^{2}$ Laboratoire des Sciences de l'Environnement Marin - CNRS UMR 6539, Institut Universitaire Européen de la Mer, \\ Place Nicolas Copernic, 29280 Plouzané, France \\ ${ }^{3}$ Centre for Integrative Ecology, School of Life and Environmental Sciences, Deakin University, Warrnambool, VIC 3280, Australia \\ ${ }^{4}$ Present address: Centre de Recherche et d'Enseignement de Géosciences de l'Environnement CEREGE (Aix Marseille Univ, \\ CNRS, IRD, Coll France), 13545 Aix-en-Provence, France
}

\begin{abstract}
The queen conch Lobatus (Strombus) gigas, a marine snail, is among the most important fisheries resources of the Caribbean region. To provide effective protection in marine reserves, a good understanding of its habitat usage is essential. Queen conches commonly inhabit marine habitats. In this study, its activity space in a marginal estuarine-like habitat, the groundwater-fed inlet of Xel-Há (Mexico) was determined using high-resolution acoustic telemetry (VEMCO Positioning System). Thirty-eight animals with syphonal lengths ranging from 80 to $200 \mathrm{~mm}$ were tagged, 1 of them with an accelerometer tag. Their trajectories were recorded for 20 mo at $5 \mathrm{~m}$ resolution in a closely spaced array of 12 receivers. Space-time kernel home ranges ranged from 1000 to $18500 \mathrm{~m}^{2}$ with an ontogenetically increasing trend. Juveniles, subadults and most adults displayed continuous, non-patchy home ranges consistent with the typical intensive feeding activity by this fast-growing gastropod. In some adults, Lévy flight-like fragmentation of home ranges was observed that may be related to feeding range expansion or other ecological drivers such as the breeding cycle. The observed small home ranges indicate that the space use of queen conch in this estuarine-like habitat is not conditioned by food availability, and despite environmental stress due to daily low-oxygen conditions, space use is comparable to that observed in more typical marine habitats. In a marine reserve context, the groundwater-fed inlet provides adequate protection of this inshore queen conch population. Such marginal habitats may play an increasingly important role in conservation management as pressure on populations increase.
\end{abstract}

KEY WORDS: Lobatus gigas - Queen conch · Acoustic telemetry $\cdot$ Home range $\cdot$ Marine protected area $\cdot$ Marginal habitat $\cdot$ Accelerometer $\cdot$ VEMCO Positioning System

\section{INTRODUCTION}

Conservation management of the queen conch Lobatus (Strombus) gigas is of considerable economic and ecological importance to the Caribbean region. This large and fast-growing marine gastropod is one of the most important fishery resources of

${ }^{*}$ Corresponding author: thomas.stieglitz@jcu.edu.au the region, and populations have been in decline for some decades as a result of substantial fishing pressure (Appeldoorn \& Baker 2013). The species has been listed under Appendix II of the Convention on International Trade in Endangered Species of Wild Fauna and Flora (CITES) since 1992. In most Caribbean nations, conch fishery management regulates

(C) The authors 2017. Open Access under Creative Commons by Attribution Licence. Use, distribution and reproduction are unrestricted. Authors and original publication must be credited. 
catch quotas and moratoriums, as well as the establishment of marine protected zones. In order to provide effective protection measures of mobile animals in marine reserves and to design sustainable fisheries strategies, a good understanding of an animal's usage of its habitat is essential (e.g. Kramer \& Chapman 1999, Glazer \& Delgado 2006, Grüss et al. 2011).

In this context, investigations of a species' home range have become a standard approach to assess space use. The home range is the geographic area to which an organism normally confines its activity (Worton 1987). This area provides information on food distribution and foraging behaviour as well as social interactions between individuals and predatorprey relationships (Swihart et al. 1988, McLoughlin \& Ferguson 2000). Home ranges are calculated from an individual animal's movement path, in the marine environment recorded by mark-recapture or acoustic telemetry surveys. In recent years, the rapid development of passive acoustic telemetry has allowed a substantial increase in detection frequency and accuracy of movement paths by long-term deployments of autonomous acoustic receiver stations. Importantly, concurrent tracking of a large number of individuals today makes studies at the population level possible (Heupel et al. 2006). Marine animal movement research has mainly focused on fast-moving (highly mobile) animals, such as mammals, sea turtles, birds (Sims et al. 2008, Hussey et al. 2015) or fishes (Alós et al. 2011, 2012). A few studies have used direct observation to investigate the movement of small and slowmoving benthic animals such as sea urchins (LauzonGuay et al. 2006) and gastropods (Seuront et al. 2007, Vannini et al. 2008). Recently, acoustic telemetry was used to study home ranges and population connectivity of abalone and octopus species (Sheel \& Bisson 2012, Coates et. al 2013).

Queen conches have an extraordinarily fast growth rate, growing to a shell length of ca. $200 \mathrm{~mm}$ within 2 to 3 yr (e.g. Appeldoorn 1988, Peel \& Aldana-Aranda 2012). It spends its first year of life buried in the sediment, and animals reach sexual maturity at around 3 to $4 \mathrm{yr}$ of age (Appeldoorn 1988). The predominant habitat of this slow-moving benthic grazer consists of seagrass beds in reef lagoons, usually offshore from the coast (e.g. Randall 1964, Stoner 1989b, Stoner et al. 1995). Conches are also found associated with sandy bottoms, macroalgae plains and rubble fields in reef lagoon settings (Randall 1964). Detrital matter and microphytobenthos represent the main food source for this species (Ray \& Stoner 1995). Queen conches have been observed to aggregate as a defence against predation pressure, forming groups up to 100000 individuals (Stoner \& Lally 1994), or in breeding aggregations (Berg et al. 1992).

A number of acoustic telemetry pilot studies in typical reef conch habitat have been carried out in recent years, chiefly by manually tracking tagged animals with a mobile receiver deployed from a moving vessel. Doerr \& Hill (2008) determined speed of travel of 50 to $100 \mathrm{~m}$ per day for adult animals in seagrass and reef habitat in the US Virgin Islands. Despite a large number of detections (more than 200000 ) of multiple animals and a considerable survey duration (1 to 12 mo per animal), no home ranges were calculated. Glazer et al. (2003) investigated the home ranges of 44 queen conches for the explicit purpose of designing marine fisheries reserves in the Florida Keys (USA). The number of sightings was low, ranging from 4 to 17 per animal in a 13 mo period. Home ranges between 50000 and $596100 \mathrm{~m}^{2}$ were determined. Delgado \& Glazer (2007) refined this work and investigated if the translocation of conches to a protected area is a valuable solution for fisheries management. They tagged native and translocated conches using acoustic telemetry and determined similar home ranges, ranging from 1676 to $189867 \mathrm{~m}^{2}$. Bissada-Gooding \& Oxenford (2009) tagged 3 conches in Barbados and calculated home ranges between 1131 and $21256 \mathrm{~m}^{2}$ (mean $11031 \mathrm{~m}^{2}$ ) for a $12 \mathrm{wk}$ period, based on a comparatively low detection rate with a maximum of 41 detections $\mathrm{wk}^{-1}$ (all conches pooled). In another Barbados reef habitat study, Phillips et al. (2010) determined smaller home ranges of 3 conches of between 5535 and $11654 \mathrm{~m}^{2}$ over a 3 mo period.

Here we report on the movement ecology of queen conch in an estuarine-like habitat in a coastal inlet on Mexico's Yucatan Peninsula. Throughout the year, large permanent inflow of low-salinity groundwater substantially modifies physicochemical conditions in the inlet, maintaining strongly stratified conditions which inhibit oxygenation of bottom waters (e.g. Back et al. 1979). Queen conches commonly inhabit locations with oceanic conditions and little to no freshwater influence (Stoner 2003), and thus this estuarine-like inlet is an uncommon habitat. We document (1) the space this species uses in this particular habitat by calculating home ranges from acoustic telemetry data continuously collected with high spatial and temporal resolution over a period of ca. $2 \mathrm{yr}$, and (2) the potential impact of ambient water salinity, temperature, dissolved oxygen and ambient light level on the movement behaviour of queen conch by monitoring overall dynamic body acceleration of 1 animal using a telemetric accelerometer. 


\section{MATERIALS AND METHODS}

\section{Study site}

The study was carried out in the small coastal inlet at Xel-Há on the northeast coast of Mexico's Yucatan Peninsula $\left(20.32^{\circ} \mathrm{N}, 87.36^{\circ} \mathrm{W}\right.$; Fig. 1a). Typical for this coastline, this inlet was formed by groundwater carbonate dissolution (Back et al. 1979, Stoessell et al. 1989, Perry et. al 2002). Connected to the Caribbean Sea by a $100 \mathrm{~m}$ wide channel, the inlet is $\sim 1 \mathrm{~km}$ long, covers an area of ca. $110000 \mathrm{~m}^{2}$ and has a maximum depth of $3.5 \mathrm{~m}$ (Fig. 1b). A persistent inflow of low-salinity groundwater maintains a permanent thermohaline stratification throughout the year, with salinity on the bottom ranging from 10 to 35 (Back et al. 1979). The main groundwater source is located in the south arm of the inlet. The bottom substrate is mostly sandy, with small and large isolated rocks, bare sand, extended macroalgal mats (Padina sp., Halimeda sp., Penicillus sp., Amphiroa sp., Acanthophora sp., Caulerpa sp. and Dictyota sp.; Peel \& Aldana-Aranda 2012), and isolated Thallasia testudinum seagrass beds. Whilst bottom cover is patchy, generalised broad-scale habitats can be defined (Fig. 1c).

Since 1995, Xel-Há has been an ecotourism park without boat traffic, and removal of fauna and flora is prohibited. A population of juvenile and adult queen conches, presently estimated at 2000 to 6000 individuals (J. Peel \& E. May pers. comm.), inhabits the inlet (Valle-Esquivel 1998, Peel \& Aldana-Aranda 2012).

Salinity, temperature and dissolved oxygen concentration in bottom water were recorded in $1.5 \mathrm{~h}$ intervals on calibrated YSI multi-parameter sondes installed in the north arm and the inner part of the
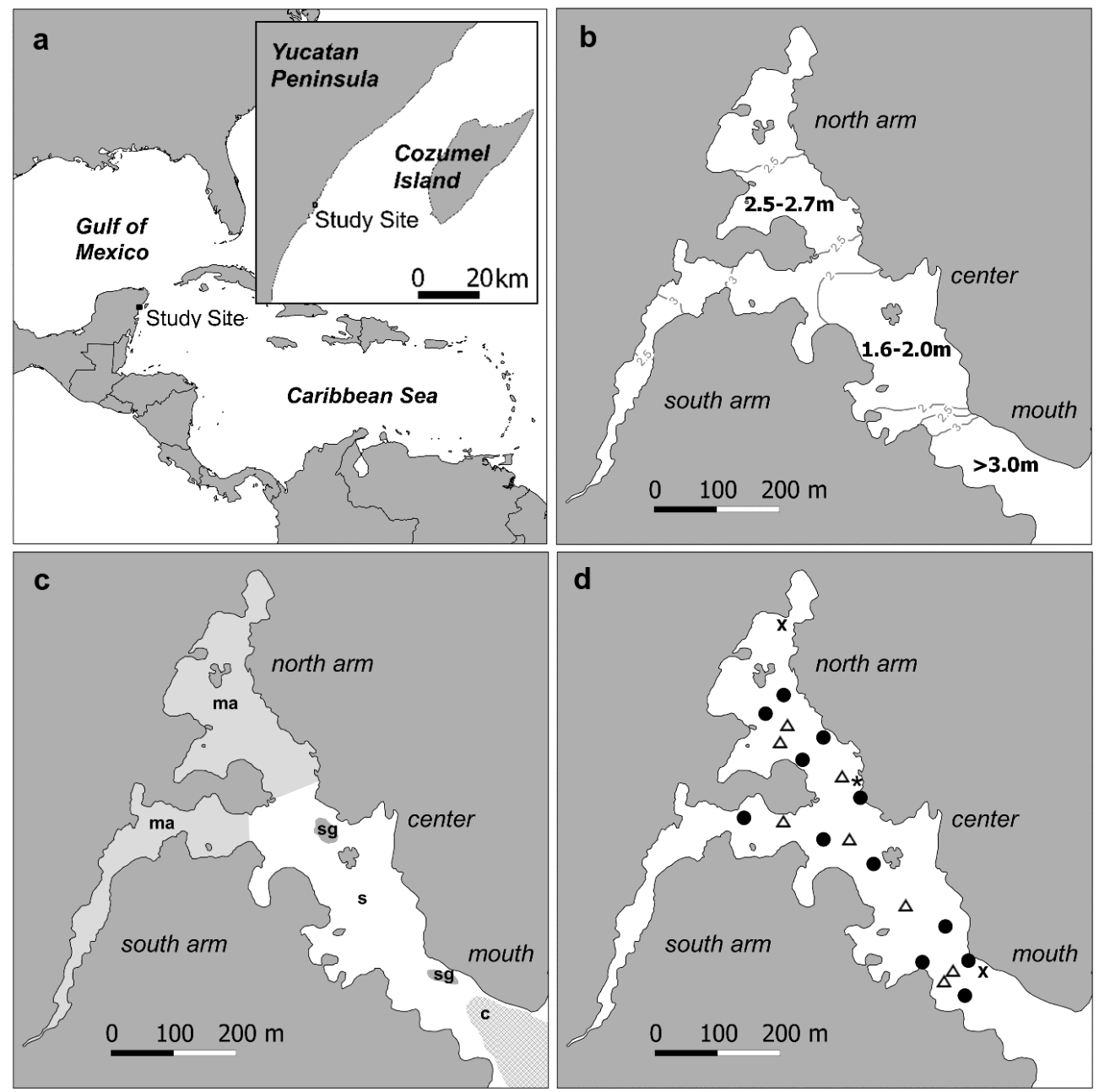

Fig. 1. (a) Location, (b) bathymetry, (c) simplified habitat map of the study site (ma: macroalgae; sg: seagrass; c: coral reef; s: bare sand) and (d) receiver network in Xel-Há inlet, Mexico. Black dots: receivers; white triangles: synchroniser tags; crosses: water quality sensors (data from the southern sensor were used in this study); asterisk: light sensor 
mouth section of the inlet (Fig. 1d). Both show virtually identical temporal patterns in the observed parameters. Data recorded at the inner part of the mouth is reported herein, which are considered representative for the conditions experienced by most animals, in particular the animal carrying a telemetric accelerometer. A HOBO ambient light level sensor was installed at sea level approximately in the centre of the inlet (Fig. 1d).

\section{Tagging and tracking}

Queen conch specimens were sampled by diving or free diving from 4 locations, i.e. 1 in each of the 4 regions of the inlet (Fig. 1b). Sites were randomly pre-determined on a map (to avoid bias due to e.g. accessibility or conch density), and conches were searched in a circular pattern from these locations. Animals in the size range sampled (80-200 mm syphonal length) are easily and equally well visible, thus avoiding a bias in sampling animals of different sizes. Although conch density is not constant, conches are found 'everywhere' in the inlet.

The syphonal length of each conch was measured from the apex of the spire to the end of the syphonal canal, and shell lip thickness was determined following methods described by Peel \& Aldana-Aranda (2012). Animals were tagged across the size classes 'juvenile', 'subadult' and 'adult' in December 2009, June 2010 and April 2011 (Table 1). Animals with syphonal length of $<150 \mathrm{~mm}$ were considered juvenile, those $>150 \mathrm{~mm}$ were considered subadult, and those with a well-developed shell lip were considered adult, following the classification of Peel \& Aldana-Aranda (2012) and Stoner et al. (2012). The size distribution of tagged animals reflects well the size distribution in the entire population (Peel \& Aldana-Aranda 2012).

The animals were temporarily relocated to a basin filled with seawater, and tagged with individually coded VEMCO V7 and V9 transmitters, preprogrammed to emit 1 ping every $8 \mathrm{~min}$. The transmitters were attached with epoxy resin and a cable tie to the highest point on the shell to allow for best possible detection probability. Combined weight of tag and resin was less than $50 \mathrm{~g}$ in air, considered negligible on shells ranging in weight from ca. 0.4 to $1.5 \mathrm{~kg}$. All possible measures were taken to reduce stress on the animals during handling; normal behaviour was observed after release. Throughout the study, no tag detached from the animals (as indicated by continuously observed movement).
Each animal was released within a few tens of metres from where it was caught. Some animals were caught and released in the southern arm of the inlet, i.e. outside the area of this study; those that moved into the survey area at a later stage throughout the survey period are considered in the analyses.

An array of 12 acoustic receivers (VEMCO VR2W) installed throughout the northern, central and southern (mouth) sections of the inlet recorded the transmissions (Fig. 1d). The permanent moorings consisted of steel rods and concrete blocks sunk into the sediment. Receivers were located in 1.5 to $3.5 \mathrm{~m}$ water depth, deployed approximately $0.5 \mathrm{~m}$ above the bottom. Receiver locations were optimised for coverage (large overlap), to avoid topographic shading from rocks where possible, but were constrained by tourism operations in this dive ecotourism park.

\section{Animal position and trajectory calculation}

The geographical position of a tagged animal was calculated at a typical accuracy of a few metres by an algorithm based on the difference in time-of-arrival at a minimum of 3 receivers using VEMCO in-house software (VEMCO Positioning System, VPS; Smith 2013; see also Espinoza et al. 2011, Coates et al. 2013). Data collected from fixed-location synchroniser tags were used to assess the quality of positioning data (Smith 2013; for details of animal position calculation, see Supplement 1 at www.int-res.com/ articles/suppl/m571p139_supp.pdf). Positioning data with a position error greater than $24 \mathrm{~m}$ (due to nonideal detection in the acoustic array) were excluded $(4.7 \%$ of the data set, Supplement 1$)$. In order to assess time scales of displacement of queen conch, the rate of movement (ROM), i.e. distance travelled per time unit for each tracked animal, was calculated on hourly, daily and weekly time scales.

In addition to this high-resolution positioning study, a preliminary study on telemetric accelerometry was carried out, whereby 1 animal was tagged with a sensor tag including a low-resolution accelerometer and transmitting data to the receiver network. These pilot data allowed us to evaluate relationships of daily movement patterns with key environmental parameters (for details of the methods, see Supplement 2 at www.int-res.com/articles/ suppl/m571p139_supp.pdf). Results from this preliminary study are reported to facilitate the design of subsequent studies using this promising additional low-cost tool in telemetry studies. 
Table 1. Data summary of tagged queen conch Lobatus gigas with vital data, detection data and interpreted trajectory and space use parameters. Size class: juvenile $(\mathrm{J})$, subadult $(\mathrm{S})$, adult $(\mathrm{A})$; release region and regions visited: south arm (S, outside survey area), north arm (N), centre (C), mouth (M). Space-time kernel home range and core are reported. Lip thickness was only measured in adults. Bottom section summarises apparent home range and core area of fixed-location synchronisation tags S01 to S07. Dates are given as dd/mm/yy

\begin{tabular}{|c|c|c|c|c|c|c|c|c|c|c|c|}
\hline $\begin{array}{l}\text { Tag } \\
\text { ID } 1\end{array}$ & $\begin{array}{c}\text { Syphonal } \\
\text { length (mm) }\end{array}$ & $\begin{array}{l}\text { Lip thickness } \\
(\mathrm{mm})\end{array}$ & $\begin{array}{l}\text { Size } \\
\text { class }\end{array}$ & $\begin{array}{l}\text { Release } \\
\text { region }\end{array}$ & $\begin{array}{c}\text { Date of } \\
\text { first record }\end{array}$ & $\begin{array}{c}\text { Date of } \\
\text { last record }\end{array}$ & $\begin{array}{c}\text { No. of } \\
\text { detections }\end{array}$ & $\begin{array}{l}\text { Trajectory } \\
\text { type }\end{array}$ & $\begin{array}{c}\text { Regions } \\
\text { visited }\end{array}$ & $\begin{array}{l}\text { Home } \\
\text { range }\left(\mathrm{m}^{2}\right)\end{array}$ & $\begin{array}{c}\text { Core } \\
\text { area }\left(\mathrm{m}^{2}\right)\end{array}$ \\
\hline T35 & 130 & & $\mathrm{~J}$ & $\mathrm{~S}$ & 09/02/11 & $14 / 09 / 11$ & 631 & 1 & $\mathrm{C}$ & 5500 & 1425 \\
\hline T38 & 204 & 13 & A & M & $18 / 06 / 10$ & 08/03/11 & 969 & 1 & M & 6950 & 1400 \\
\hline $\mathrm{T} 42$ & 180 & & $\mathrm{~S}$ & $\mathrm{~S}$ & 08/03/11 & $24 / 05 / 11$ & 108 & 2 & $\mathrm{~N}, \mathrm{C}, \mathrm{M}$ & 8875 & 2675 \\
\hline $\mathrm{T} 43$ & 105 & & $\mathrm{~J}$ & $\mathrm{~S}$ & 05/02/11 & $24 / 05 / 11$ & 164 & 2 & $\mathrm{C}, \mathrm{M}$ & 5575 & 1325 \\
\hline $\mathrm{T} 44$ & 202 & & $\mathrm{~S}$ & $\mathrm{C}$ & $26 / 05 / 10$ & 09/09/11 & 936 & 1 & M & 6200 & 1575 \\
\hline $\mathrm{T} 46$ & 208 & 8 & $\mathrm{~A}$ & $\mathrm{~N}$ & $16 / 12 / 09$ & $13 / 07 / 10$ & 1198 & 2 & $\mathrm{~N}, \mathrm{C}, \mathrm{M}$ & 13475 & 3675 \\
\hline T47 & 235 & & $\mathrm{~S}$ & $\mathrm{C}$ & 20/12/09 & 03/07/11 & 139 & 1 & M & 3025 & 675 \\
\hline T51 & 203 & & $\mathrm{~S}$ & $\mathrm{C}$ & $19 / 12 / 09$ & $07 / 05 / 10$ & 1343 & 1 & $\mathrm{~N}, \mathrm{C}$ & 4400 & 1050 \\
\hline T53 & 213 & 4 & A & $\mathrm{N}$ & 16/12/09 & $17 / 04 / 10$ & 270 & 2 & $\mathrm{~N}, \mathrm{C}, \mathrm{M}$ & 6975 & 1750 \\
\hline T55 & 130 & & $\mathrm{~J}$ & $\mathrm{~N}$ & $19 / 12 / 09$ & $23 / 06 / 11$ & 2634 & 2 & $\mathrm{~N}, \mathrm{C}$ & 5125 & 900 \\
\hline T56 & 70 & & $\mathrm{~J}$ & $\mathrm{~N}$ & 16/12/09 & $22 / 08 / 11$ & 4186 & 1 & $\mathrm{~N}$ & 6075 & 1425 \\
\hline T57 & 92 & & $\mathrm{~J}$ & $\mathrm{~N}$ & $17 / 12 / 09$ & $24 / 05 / 10$ & 454 & 1 & $\mathrm{~N}$ & 5050 & 1250 \\
\hline T58 & 190 & & $\mathrm{~S}$ & $\mathrm{~S}$ & $22 / 08 / 10$ & 07/09/10 & 213 & 1 & $\mathrm{C}$ & 2225 & 700 \\
\hline T59a & 180 & & $\mathrm{~S}$ & $\mathrm{~N}$ & $17 / 06 / 10$ & 03/02/11 & 7053 & 1 & $\mathrm{~N}, \mathrm{C}$ & 10950 & 2675 \\
\hline T59b & 183 & 10 & $\mathrm{~A}$ & M & $12 / 04 / 11$ & $14 / 10 / 11$ & 1423 & 1 & $\mathrm{M}$ & 8675 & 1825 \\
\hline $\mathrm{T} 60$ & 190 & & $\mathrm{~S}$ & $\mathrm{~N}$ & $17 / 06 / 10$ & $03 / 04 / 11$ & 5284 & 1 & $\mathrm{~N}$ & 2075 & 350 \\
\hline T62 & 180 & & $\mathrm{~S}$ & M & $12 / 04 / 11$ & $13 / 06 / 11$ & 1123 & 1 & M & 2375 & 600 \\
\hline T63 & 186 & & $\mathrm{~S}$ & M & $12 / 04 / 11$ & $12 / 10 / 11$ & 2427 & 1 & M & 2500 & 600 \\
\hline T64 & 214 & 3 & $\mathrm{~A}$ & M & $12 / 04 / 11$ & $12 / 10 / 11$ & 1247 & 1 & M & 4450 & 1075 \\
\hline T65 & 113 & & $\mathrm{~J}$ & M & $12 / 04 / 11$ & $18 / 10 / 11$ & 6797 & 1 & $\mathrm{M}$ & 4550 & 450 \\
\hline T66 & 203 & 4 & $\mathrm{~A}$ & M & $14 / 04 / 11$ & 08/06/11 & 1510 & 1 & $\mathrm{M}$ & 5500 & 1650 \\
\hline T68 & 208 & & $\mathrm{~S}$ & $\mathrm{~S}$ & $03 / 07 / 11$ & $18 / 10 / 11$ & 1258 & 2 & $\mathrm{~N}, \mathrm{C}$ & 9375 & 2825 \\
\hline T69 & 199 & 5 & A & $\mathrm{S}$ & $06 / 05 / 11$ & $04 / 07 / 11$ & 843 & 2 & $\mathrm{C}, \mathrm{M}$ & 8600 & 2400 \\
\hline $\mathrm{T} 70$ & 217 & 4 & A & $\mathrm{C}$ & $14 / 04 / 11$ & $14 / 07 / 11$ & 1105 & 2 & $\mathrm{~N}, \mathrm{C}, \mathrm{M}$ & 10400 & 3025 \\
\hline $\mathrm{T} 71$ & 197 & 7 & $\mathrm{~A}$ & $\mathrm{C}$ & $19 / 04 / 11$ & $18 / 10 / 11$ & 6608 & 1 & $\mathrm{~N}, \mathrm{C}$ & 11375 & 2950 \\
\hline T72 & 221 & 3 & $\mathrm{~A}$ & M & $12 / 04 / 11$ & $08 / 07 / 11$ & 1899 & 1 & $\mathrm{M}$ & 5275 & 1525 \\
\hline $\mathrm{T} 73$ & 183 & & $\mathrm{~S}$ & $\mathrm{~N}$ & $09 / 04 / 11$ & $14 / 10 / 11$ & 5524 & 2 & $\mathrm{~N}, \mathrm{C}, \mathrm{M}$ & 11075 & 1575 \\
\hline $\mathrm{T} 74$ & 233 & 6 & A & $\mathrm{N}$ & 08/04/11 & 03/07/11 & 5781 & 2 & $\mathrm{~N}, \mathrm{C}, \mathrm{M}$ & 12950 & 3700 \\
\hline $\mathrm{T} 75$ & 220 & & $\mathrm{~S}$ & $\mathrm{~N}$ & 08/04/11 & 04/07/11 & 4217 & 1 & $\mathrm{~N}$ & 7075 & 1750 \\
\hline $\mathrm{T} 76$ & 212 & 2 & $\mathrm{~A}$ & $\mathrm{C}$ & $11 / 04 / 11$ & $18 / 10 / 11$ & 5413 & 1 & $\mathrm{~N}, \mathrm{C}$ & 9050 & 2450 \\
\hline T77 & 175 & & $\mathrm{~S}$ & $\mathrm{C}$ & $12 / 04 / 11$ & $18 / 10 / 11$ & 995 & 1 & $\mathrm{C}$ & 5225 & 925 \\
\hline T78 & 114 & & $\mathrm{~J}$ & $\mathrm{C}$ & $12 / 04 / 11$ & $01 / 07 / 11$ & 614 & 1 & $\mathrm{C}$ & 1450 & 375 \\
\hline $\mathrm{T} 79$ & 126 & & $\mathrm{~J}$ & $\mathrm{~N}$ & $11 / 04 / 11$ & 08/08/11 & 929 & 1 & $\mathrm{~N}$ & 1000 & 200 \\
\hline T80 & 204 & & $\mathrm{~S}$ & $\mathrm{~N}$ & $11 / 04 / 11$ & $18 / 10 / 11$ & 5372 & 1 & N,C & 6050 & 1150 \\
\hline T81 & 214 & 4 & $\mathrm{~A}$ & $\mathrm{~N}$ & $11 / 04 / 11$ & $14 / 10 / 11$ & 8771 & 2 & $\mathrm{~N}, \mathrm{C}, \mathrm{M}$ & 18500 & 4475 \\
\hline T82 & 208 & 11 & $\mathrm{~A}$ & $\mathrm{~S}$ & $01 / 05 / 11$ & $03 / 07 / 11$ & 1977 & 2 & $\mathrm{~N}, \mathrm{C}, \mathrm{M}$ & 13450 & 3925 \\
\hline T85 & 220 & 4 & A & $\mathrm{S}$ & $20 / 04 / 11$ & 08/06/11 & 1503 & 2 & $\mathrm{C}, \mathrm{M}$ & 7375 & 2000 \\
\hline T86 & 195 & & $\mathrm{~S}$ & $\mathrm{~N}$ & 05/04/11 & 07/10/11 & 10232 & 1 & $\mathrm{~N}, \mathrm{C}$ & 7050 & 1775 \\
\hline S01 & & & & $\mathrm{N}$ & $27 / 12 / 09$ & $18 / 10 / 11$ & 13319 & & & 725 & 150 \\
\hline S02 & & & & $\mathrm{C}$ & $17 / 12 / 09$ & $18 / 10 / 11$ & 1566 & & & 1000 & 175 \\
\hline S03 & & & & $\mathrm{N}$ & $16 / 12 / 09$ & $18 / 10 / 11$ & 22240 & & & 525 & 125 \\
\hline S04 & & & & M & $17 / 12 / 09$ & $14 / 10 / 11$ & 4322 & & & 550 & 125 \\
\hline S05 & & & & $\mathrm{C}$ & $16 / 12 / 09$ & $18 / 10 / 11$ & 65494 & & & 975 & 175 \\
\hline S06 & & & & $\mathrm{N}$ & $18 / 01 / 10$ & $13 / 10 / 11$ & 11654 & & & 1100 & 175 \\
\hline S07 & & & & M & $19 / 12 / 09$ & $13 / 01 / 11$ & 558 & & & 650 & 150 \\
\hline
\end{tabular}

\section{Home range}

Home range was calculated by fitting a utilization distribution probability function (95\% UD) to an individual's trajectory at $5 \times 5 \mathrm{~m}$ cell-size grid using 2 estimators: the kernel method described by Worton
(1987) and the space-time kernel (STK) method described by Katajisto \& Moilanen (2006) (detailed formulas are given in the respective publications). In addition, the $50 \%$ UD was calculated, which is considered the core area of an animal's space use (Vander Wal \& Rodgers 2012). In the STK method, detec- 
tions spaced further in time or space are given greater weight (Katajisto \& Moilanen 2006). Smoothing parameter values $h_{s}$ and $h_{t}$ required for the calculation of the UD estimators are based on the spatial and temporal scales of interest (Katajisto \& Moilanen 2006). $h_{s}$ was set at $5 \mathrm{~m}$ corresponding to the grid size, and $h_{t}$ was set at $1 \mathrm{~d}$.

STK home ranges (95\% UD) and core areas (50\% UD) were chosen for interpretation for 3 reasons: STK was developed (1) to account for temporally unevenly distributed positioning. VPS trajectories have missing values when signal transmission by the tags is not sufficiently strong or when transmission is obstructed by rocks; (2) to avoid a bias towards smaller home ranges when a large number of detections is closely spaced together-as is the case for slowmoving animals like queen $\mathrm{conch}_{\text {; }}$ and (3) to give relatively greater weight to 'excursions' from the core area. For these slow-moving animals, it is suggested that all excursions should be included in the home range, whereas for fast-moving animals, excursions e.g. due to flight from predators may not be appropriate to be included in the home range (depending on the interpretation of home range). STK home ranges should thus be considered as the conservative approach when interpreting them as the 'minimal space requirement' in terms of marine reserve requirements. Kernel home ranges are also provided for comparison with home ranges calculated in previous studies which only used kernel methods.

In total, 38 animal trajectories were analysed, and individual weekly and monthly home ranges were calculated for time periods where more than 30 VPS detections per time interval (week or month) were available (Katajisto \& Moilanen 2006). In order to establish a measure of uncertainty in home range calculations derived from VPS positions, the 'apparent' home range of the cloud of positions of the fixedlocation (non-mobile) synchronisation tags was calculated in a similar fashion. The area calculated from the synchroniser cloud position was compared with queen conch home ranges using a Wilcoxon nonpaired test. To establish whether there were differences between the different methods used to determine home range, the UD estimators (kernel and STK) were compared using a Wilcoxon paired test with a Holm probability correction for multiple tests. Subsequently, a Mann-Kendall non-parametric test was used to detect trends on monthly home range time series. Correlations between home range and environmental parameters were tested using a Pearson correlation test. All statistical analyses and home range calculations were performed in $\mathrm{R}$ (version 2.15,
R Development Core Team 2011). Spatial data were visualised in Quantum GIS (version 1.8.0 Lisboa). Means are reported as mean \pm 1 SE estimate throughout the manuscript.

\section{RESULTS}

\section{VPS performance and ROM evaluation}

In total, we recorded 107443 VPS locations of 38 animals over the 22 mo observation period. Note that $89.4 \%$ of all data had a calibrated horizontal positioning error of $<14 \mathrm{~m}$ (Supplement 1). This data set is thus of very high positioning accuracy, largely due to the small distances and adequate receiver positioning in this study.

Calculated ROM or 'travel-distance' clearly document small rates of movement as expected for a marine snail; $99.6,90.0$ and $47.1 \%$ of distance travelled was $\leq 10 \mathrm{~m}$ on a $1 \mathrm{~h}, 1 \mathrm{~d}$ and $1 \mathrm{wk}$ time scale, respectively. For the purpose of space use estimation in home range analysis, on average the animals can be considered as near-stationary (on 5 to $10 \mathrm{~m}$ spatial scales) for periods of $<1 \mathrm{wk}$, taking both small rate of movement and positioning error (both on 5-10 m scales) into account.

\section{Trajectories and home ranges}

The 38 queen conch trajectories analysed for home range varied in duration between 16 and $613 \mathrm{~d}$ (mean $\pm \mathrm{SE}=185 \pm 23 \mathrm{~d}$ ). The number of computed VPS positions ranged from 108 (T42) to 10232 (T86), with a mean of $2714 \pm 436$ detections per trajectory (Table 1).

Visual inspection of trajectories indicates 2 distinct types of movement behaviour (Fig. 2). Type 1 trajectories are characterised by a highly localised distribution of VPS positions confined to a small portion of the inlet, indicating that these individuals have a small, usually unfragmented home range (Fig. 3), whereas Type 2 trajectories contain segments displaying greater movements over long distances that connect 2 or more patches (i.e. more heavily used areas).

Mean home range (95\% UD) over the observation period was $4864 \pm 416 \mathrm{~m}^{2}$ for the kernel and $6954 \pm$ $616 \mathrm{~m}^{2}$ for the STK (Fig. 4), with a mean core area (50\% UD) of $450 \pm 75 \mathrm{~m}^{2}$ and $1629 \pm 168 \mathrm{~m}^{2}$, respectively. Differences between Type 1 and Type 2 trajectories were significant for STK home ranges (95\% UD), but not for kernel. For the core areas ( $50 \%$ UD), 

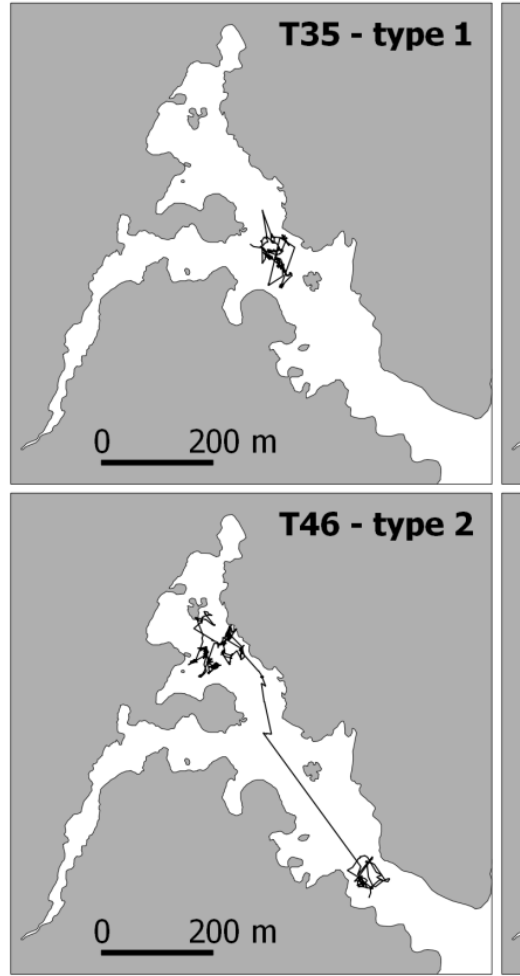
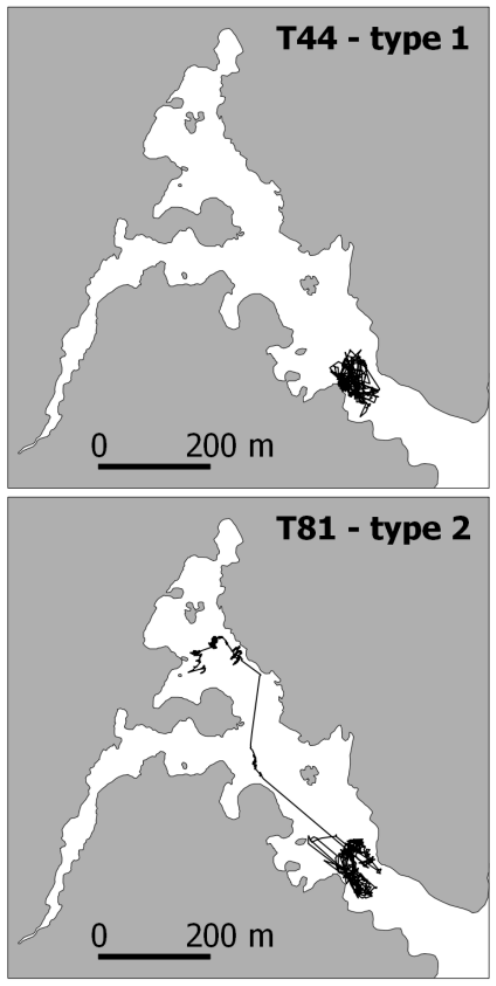
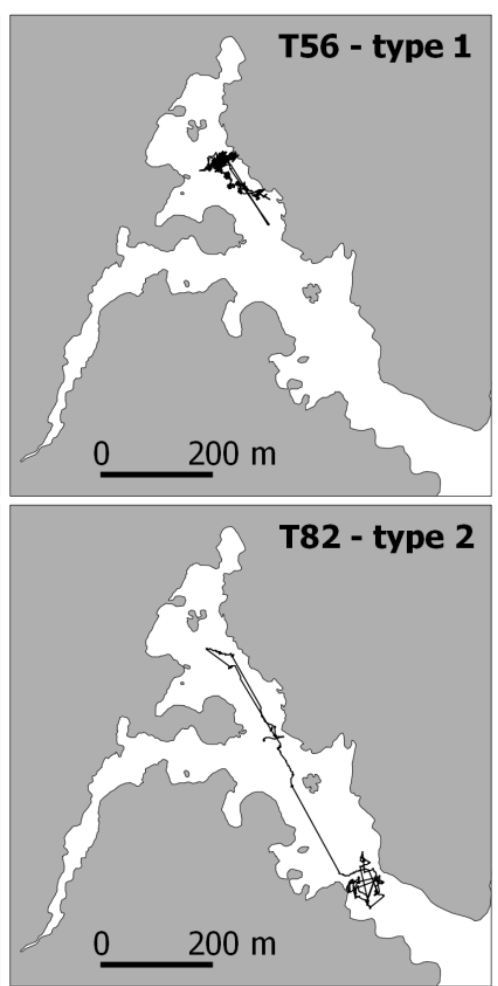

Fig. 2. Typical Type 1 (top row) and Type 2 (bottom row) trajectories of queen conches Lobatus gigas. The animals' tag ID codes are indicated in each panel
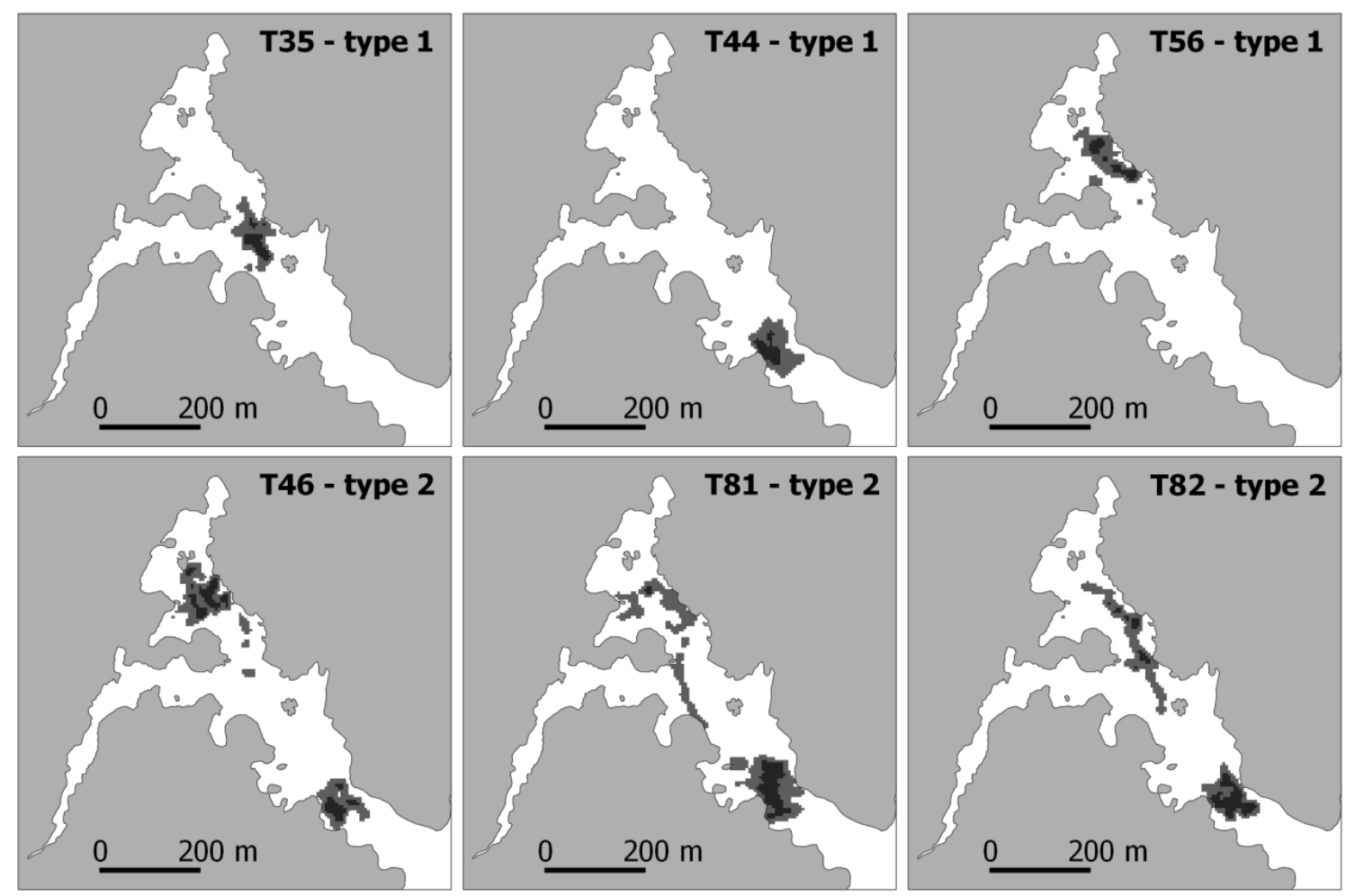

Fig. 3. Space-time kernel home range (95\% utilization distribution, UD, in grey) and core area (50\% UD, in black) of typical Type 1 and Type 2 trajectories of queen conches Lobatus gigas (same animals as in Fig. 2) 


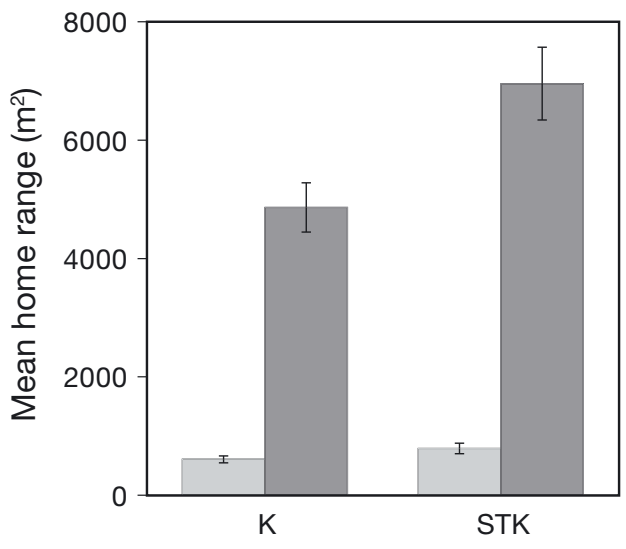

Fig. 4. Mean \pm SE home range (95\% utilization distribution, UD) of queen conches Lobatus gigas (in dark grey) in XelHá inlet over the full observation period (December 2009 to October 2011) calculated with kernel (K) and space-time kernel (STK) estimators, together with 'apparent' home range of fixed-location synchronisation tags (light grey)

they were significant only for the STK (Wilcoxon paired tests, $\mathrm{p}<0.05$ ). 'Apparent' home ranges of fixed-location synchronisation tags were significantly smaller than true animal home ranges (Wilcoxon $\mathrm{p}<$ 0.05; Table 1, Fig. 4).

In order to assess trends in home range size, average monthly STK home ranges were assessed, separated by size class and habitat type (Fig. 5a). Note that no relationship between monthly home range and environmental parameters (salinity, temperature or oxygen concentration) could be established. However, at the daily scale the queen conch equipped with a telemetric accelerometer exhibited an increase in movement rate with an increase in oxygen concentration (Supplement 2). A clear increase in

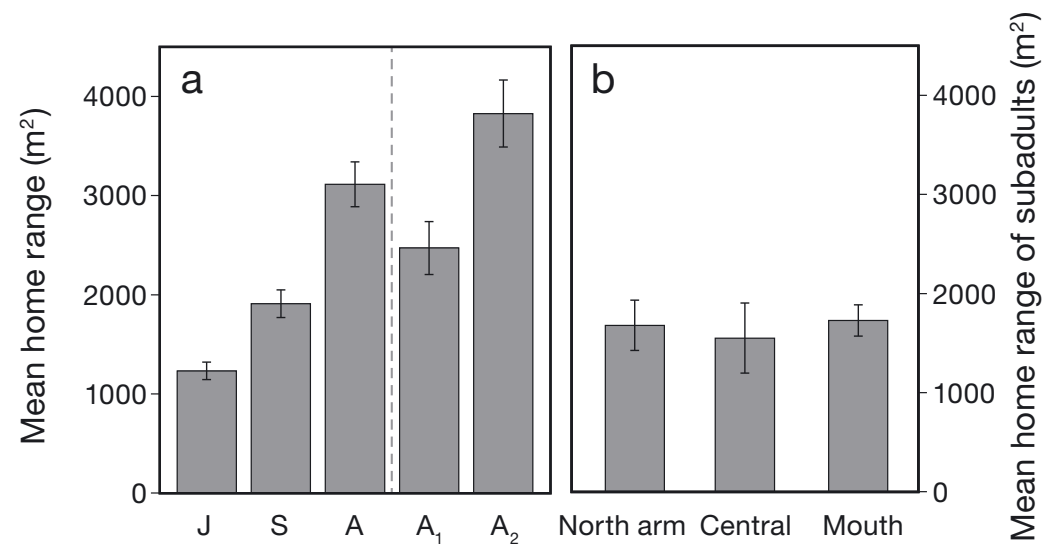

Fig. 5. (a) Mean \pm SE monthly home range of queen conches Lobatus gigas in Xel-Há inlet for juveniles (J), subadults (S) and adults (A). Adults are further separated by trajectory type $\left(\mathrm{A}_{1}\right.$ and $\mathrm{A}_{2}$ for Type 1 and Type 2 trajectories, respectively). (b) Mean \pm SE monthly home range of subadults in different regions of the inlet. No differences were found among the 3 regions average home range size with animal size (or age) is evident. Juveniles used on average about half the home range of adults, and both Type 1 and Type 2 home ranges of adults were consistently larger than those of juveniles and subadults (Wilcoxon, $\mathrm{p}<0.05$ ).

Whilst micro-habitats are patchy in the inlet, 3 broad-scale habitats including bottom types that are commonly found in typical conch habitat can be distinguished: (1) the north arm with depths $>2.5 \mathrm{~m}$ and macroalgae cover, (2) the shallow $(<2.0 \mathrm{~m}$ depth) and more or less bare sandy central section with isolated seagrass beds, and (3) the deep (>3 m) and bare section at the mouth (Fig. 1c). Home ranges were similar across the different habitat types (Fig. 5b; Wilcoxon $p>0.05$ ). Note that in order to remove potential effects of animal size class when comparing home range across habitats, only data from the size class subadults (which were found in all habitats) were included in this analysis (Fig. 5b).

Monthly home range time series show an increasing trend for juveniles and subadults (Mann-Kendall, $\mathrm{p}<0.001$, tau $=0.513$ and 0.455 ) but not for adults (Mann-Kendall, $\mathrm{p}>0.05$, tau $=0.153$; Fig. 6). This trend is also clearly observed in the monthly cumulative home range of the small conches T47, T55 and T56 tagged early on in the study in December 2009 (Fig. 7), with an initial period corresponding to the juvenile phase of the animal with a small home range and a second period of fast increase of home range size corresponding to the subadult/adult phase. A correlation is also observed between syphonal length at tagging and home range size (Pearson correlation test, $\mathrm{r}=0.38$ for STK $95 \%$ UD, $\mathrm{p}<0.05$ ). 


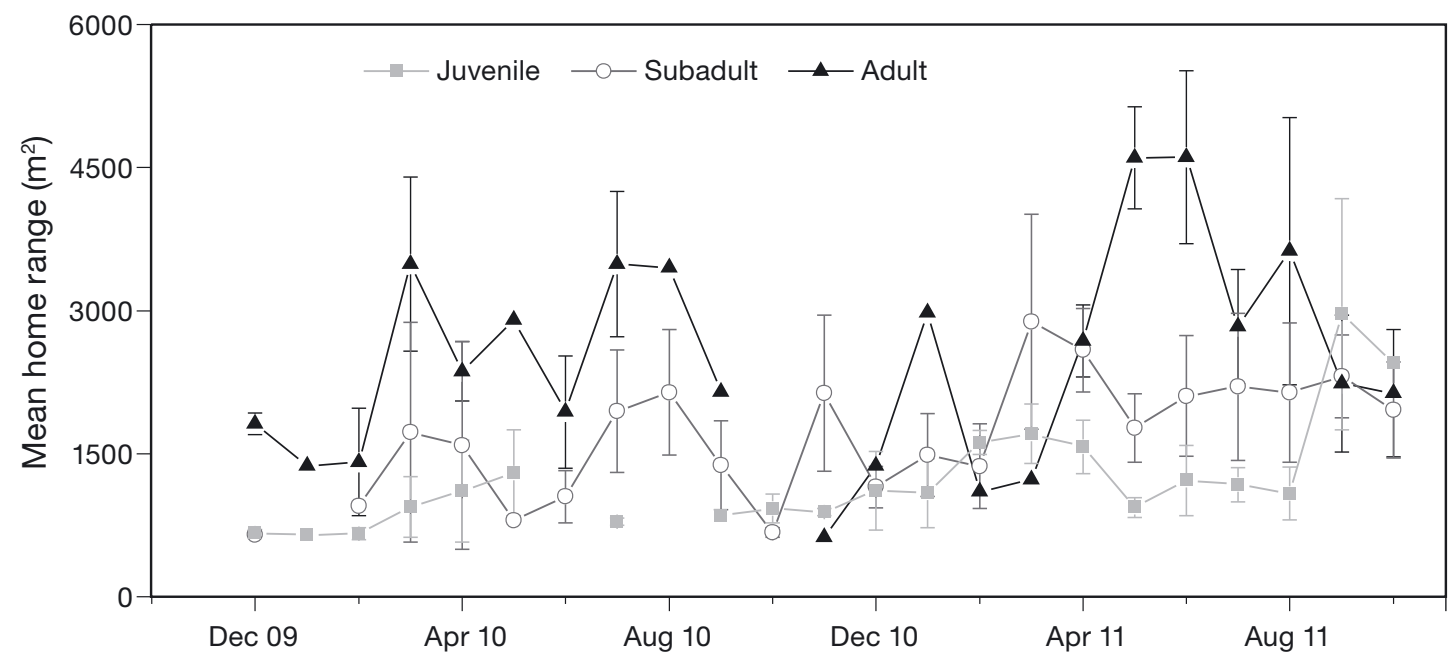

Fig. 6. Time series of mean \pm SE monthly home range of juvenile, subadult and adult queen conches Lobatus gigas in Xel-Há inlet
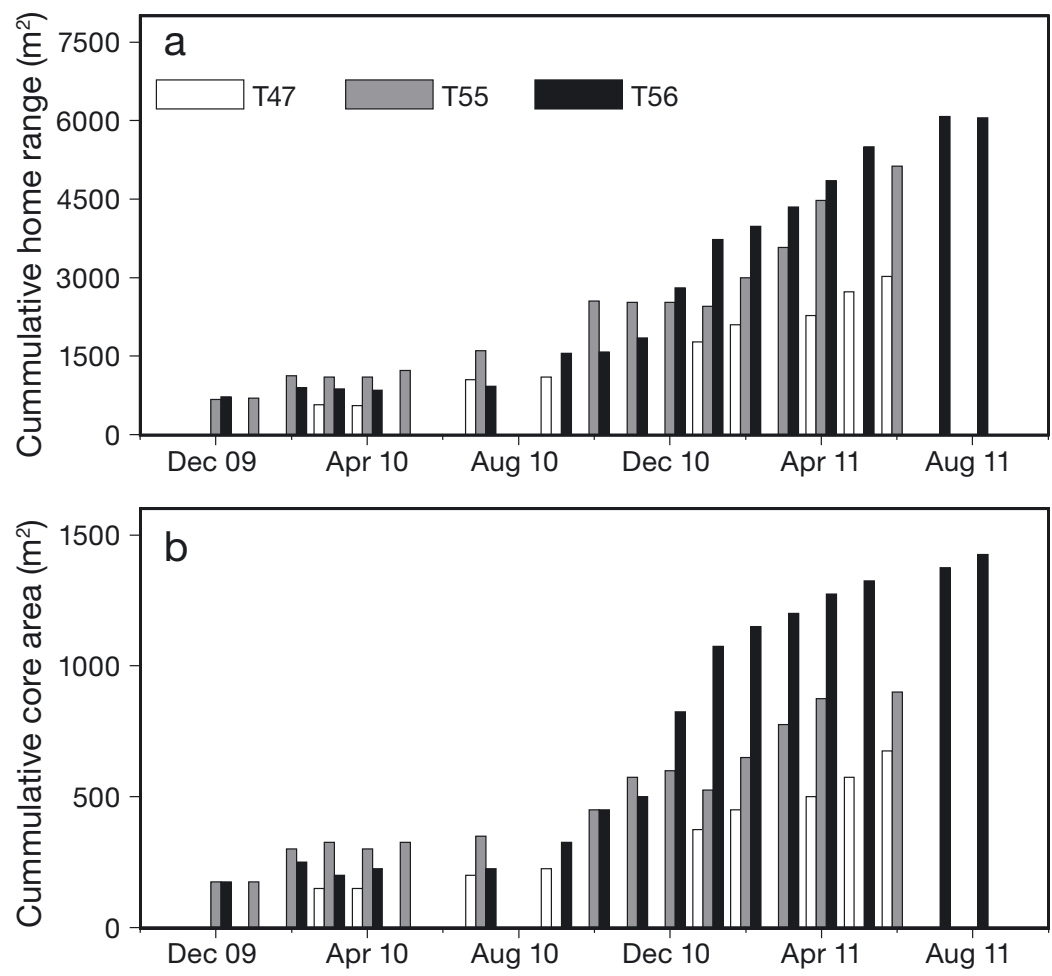

Fig. 7. Cumulative monthly (a) home range and (b) core area of 3 representative queen conches Lobatus gigas (tags T47, T55 and T56). Home ranges and core areas during the juvenile life stage show little variation; subadult life stages correspond to the second part of the time series with a rapid increase in home range and core area towards a plateau level

(Fig. S1). This considerable freshening of bottom waters is associated with strong wind events resulting in temporary breakdown of the estuarine stratification and vertical mixing of bottom water with overlying freshwater.
Dissolved oxygen concentration and temperature were identified as the 2 environmental factors best explaining the movement rate of the animal equipped with a telemetric accelerometer (Table S1 in Supplement 2). The movement rate increased with increasing dissolved oxygen concentration and decreased with increasing temperature, while salinity and light had relatively little effect on the movement rate compared to dissolved oxygen or temperature (Table S1 in Supplement 2).

\section{DISCUSSION}

\section{High-resolution acoustic telemetry of slow-moving animals}

VPS high-resolution acoustic telemetry is a useful tool for the detailed study of space use by benthic species (e.g. Espinoza et al. 2011, Moland et al. 2011). Our study illustrates that VPS is well suited to studies of slowmoving species such as queen conch, providing long-term movement paths on spatial resolution of usually better than $15 \mathrm{~m}$, and allowing the calculation of home ranges on correspondingly small spatial scale and resolution. Here we briefly discuss 2 potential limitations of VPS data of slow-moving animals. 
From the VPS trajectories, 2 conspicuously different movement types of individuals can be distinguished. Home ranges of 25 of 38 tracked animals are small and un-fragmented (Type 1), with the remaining (Type 2) movements containing segments displaying faster movements over 'long' distances, appearing as straight lines between 2 denser clouds of locations not unlike Lévy flight trajectories (Fig. 2). In such cases, space use is underestimated and a fragmentation of home range is observed (Fig. 3). Fragmentation of kernel-based home range estimates can occur when movement data are either incomplete or when movement between fragments occurs relatively fast (Løkkeborg et al. 2002, Katajisto \& Moilanen 2006). VPS positioning relies on concurrent detections at 3 or more receiver stations for triangulation computation. In topographically complex environments such as Xel-Há, signal reception from transmitters can be compromised by acoustic shading near physical obstacles like rocks or reefs, resulting in incomplete positioning time series. For this study, we consider these methodological constraints to be negligible, because segments connecting 'heavyuse' areas are consistently travelled fast (within a few days) and thus constitute only a small part of the extended observation period.

At a sub-daily or daily timescale, these trajectories and home ranges are not well suited for detailed analysis. The ROM shows that $95.1 \%$ of the distance travelled in $1 \mathrm{~h}$ is $\leq 5 \mathrm{~m}(99.6 \% \leq 10 \mathrm{~m})$, which is in the same order as the cumulative positioning uncertainty. Whilst highly mobile species may move on sufficiently large spatial scales to allow for an in-depth analysis of short-term movement behaviour, e.g. by applying a range of movement models (e.g. Turchin 1998) using positioning systems like VPS, for the slow-moving queen conch an alternative approach is required. We demonstrate the potential usefulness of telemetric accelerometry for this purpose in Supplement 2.

In summary, the positioning accuracy and frequency of detection of VPS in this study is considered to be appropriate to determine detailed and accurate space use requirements of queen conch in small habitats. An improvement in positioning in future studies of slow-moving animals could be achieved by deploying a larger number of receiver stations.

\section{Space use by queen conches}

Home ranges in the estuarine-like inlet of Xel-Há ranged from 1000 to $18500 \mathrm{~m}^{2}$ over the 23 mo observation period. These values are close to those reported by Phillips et al. (2010), ranging from 5535 to 11654 $\mathrm{m}^{2}$ in a reef setting which were determined from only a small number of detections over a short period of 3 mo. In open coastal waters off of Florida, home ranges from 50000 to $596610 \mathrm{~m}^{2}$ and $27705 \mathrm{~m}^{2}$ to $189867 \mathrm{~m}^{2}$ were found in 2 consecutive studies (Glazer et al. 2003, Delgado \& Glazer 2007) over time scales comparable to this study. This is almost a factor of 10 over those found in Xel-Há. Note that in these 2 studies, areas were calculated based on a small sample size of animal locations $\left(\mathrm{n}_{\max }=17\right.$ for Glazer et al. 2003, $\mathrm{n}_{\max }=20$ for Delgado \& Glazer 2007), which tends to increase home range based on a kernel estimator (Seaman \& Powell 1996, Seaman et al. 1999), but is unlikely to result in a factor-10 effect. It is reasonable to conclude that the (likely site-specific) home ranges in the inlet of Xel-Há are smaller than those observed in open-water environments. Limitation of habitat size by physical obstacles like coastlines can have an impact on home range by reducing surface usable by animals (e.g. Dees et al. 2010). On one hand, this border effect may partially explain reduced home ranges in the inlet; on the other hand, the observed trajectories show that individual queen conches limit their activity space in Xel-Há to a small fraction of the inlet over periods of many months and thus do not use all the space available in the inlet $\left(>100000 \mathrm{~m}^{2}\right)$. This suggests that the inlet borders may not greatly affect home range size on the time scale of our observation.

Among the ecological parameters that explain the home range of species, availability and spatial distribution of food sources are fundamental (McLoughlin \& Ferguson 2000). McLoughlin \& Ferguson (2000) described 3 theoretical home range cases based on food availability and on foraging strategy: (1) when food is abundant and easily accessible, a small home range with high overlap is observed. Such ecosystems can support high numbers of individuals; (2) when food availability and accessibility are intermediate, a larger home range with a larger overlap is observed; and (3) when food availability and accessibility are low, the largest home range sizes and highest overlap are observed.

The queen conch population of Xel-Há inlet displays high growth rates typical for this species (Valle Esquivel 1998, Peel \& Aldana-Aranda 2012), which is supported by intensive grazing on microphytobenthic and detrital matter (Stoner 1989a, 2003, Stoner et al. 1995). At the same time, as observed in Xel-Há, overlap of home ranges and aggregations in this species are well documented (e.g. Berg et al. 1992, Stoner \& Lally 1994). This suggests that queen conch 
home ranges in Xel-Há likely are of the first case described by McLoughlin \& Ferguson (2000), with individuals sharing space due to large amount of resources available. Recent population size estimates of 2000 to 6000 by Peel \& Aldana-Aranda (2012) indicate that the inlet is able to provide sufficient resources for a considerable population, in other words that the movement pattern is not limited by food availability. The total amount of food available in Xel-Há remains unquantified, but persistent large algal mats and isolated seagrass beds with microphytobenthic epiphytes suggest that it is abundant. It is interesting to note that home ranges in what visually appears to be bare sand in the shallow centre section are not reduced in comparison with other habitats (Fig. 5b), suggesting that food resources are not obligatorily tied to macroscopic growth, and that perhaps microphytobenthos on sandy seafloor are an equally valuable resource for queen conch.

\section{Ontogenetic variations of home range}

In many species, home ranges are related to animal size or age, for example in mammals (Swihart et al. 1988), lizards (Turner et al. 1969) or fishes (Kramer \& Chapman 1999). Our study demonstrates that such a size (age)-range relationship also exists for the queen conch. Home ranges of juveniles were consistently smaller than those of adults (Fig. 5a). A slight trend towards increasing average monthly home range with time was observed in subadult animals (Fig. 6). This trend is consistent with the age (size)dependency of home range size: as animals grow older, they transition from comparatively small to larger home ranges (Fig. 7). In marine habitats, a size-dependent habitat differentiation (but not home range) has been observed, with juvenile queen conches found in shallow, inshore seagrass meadows and adults preferentially found in deeper algal plains and seagrass meadows distinct from juveniles (Stoner 1989a, Sandt \& Stoner 1993). There appears to be no habitat preference in Xel-Há (Fig. 5b, Table 1). A priori, an increase in home range with age may be related to (1) older and thus larger animals requiring more food or simply travelling faster and farther than smaller ones, or (2) other activities requiring energy, e.g. exploring the environment to locate new sources of food or potential mating partners.

The use of multiple patches (i.e. heavily used areas) within a home range (trajectory Type 2) has been documented for a range of terrestrial and marine species and has often been linked to changes in food quality and/or availability (e.g. large herbivores, Searle et al. 2005; sea turtles, Christiansen et al. 2017; whales, Dalla Rosa et al. 2008). Animals often leave a patch before completely depleting it, usually when its quality drops below the average quality of the whole site (Charnov 1976, Searle et al. 2005). Stoner (1989b) found that high densities of large juvenile queen conches (up to $200 \mathrm{~m}^{-2}$ ) can consume most of the detrital ( 75\%) and epiphytic ( $60 \%)$ biomass over the course of a few weeks. At lower densities $\left(0.1\right.$ to $1.4 \mathrm{~m}^{-2}$, comparable to densities found in Xel-Há), Stoner et al. (1995) found that zones where queen conches were excluded contained 3.8 times more detrital matter compared to zones containing animals. This suggests that queen conches can deplete much of their food resources even at low densities. While food sources were not quantified in the Xel-Há inlet, seasonal cycles may impact their quality/availability (Medina-Gómez \& Herrera-Silveira 2006, Wai et al. 2008). Further investigations would be required to determine in detail how variations in the food quality/availability may impact the movement of queen conches.

The conspicuous difference in Type 1 and Type 2 trajectories with and without fragmentation, respectively, suggests an underlying different ecological reason for these movement types other than feeding patterns alone. An alternative explanation for the considerable difference in trajectories is the search for mating partners, i.e. a relation with the breeding cycle. Type 1 trajectories were observed in animals of all size classes, and are consistent with a typical feeding behaviour not limited by food availability (see above). In contrast, Type 2 trajectories were predominantly observed in adult animals, but also in some animals that were classified as subadults and 1 juvenile at the time of tagging. For the underlying behaviour to be related to the breeding cycle, one would expect that only adult animals display this behaviour. It is important to consider that the classification into age/size groups applied at the time of tagging, i.e. at the start of the observations. Animals will change size (and class) to eventually reach maturity, likely within a few months for the animals tracked in this study given their already advanced stage of shell growth (e.g. Appeldoorn 1988). As an example, an animal classified as juvenile in December 2009 was observed to expand its home range from Type 1 to Type 2 after 1.5 yr (in May 2011). Considering the well-documented fast growth rates, it is likely that this animal had reached maturity at the time of the observation of home range expansion, and thus would be expected to behave like other adult ani- 
mals. Similar migration patterns occur during breeding (Stoner \& Sandt 1992), and we suggest that this range expansion associated with Type 2 movements may thus be at least in part related to the species' breeding cycle. It is interesting to note that Type 2 movements and corresponding home range expansion are particularly evident in the period April/May 2011 (Fig. 6). Peel \& Aldana-Aranda (2012) noted an increase in juvenile recruitment following the period of the Type 2 movement (around October).

\section{Implications for conservation management}

Successful conservation management depends greatly on a good understanding of a species' habitat use and interactions with the environment (Grüss et al. 2011, Lea et al. 2016). In this study, we document movement behaviour and habitat use of the queen conch in a groundwater-fed estuarine-like habitat. We consider this habitat to be marginal for this marine species because of the substantial variations in environmental conditions caused by the continuous groundwater inflow not usually observed in the conch's typical marine habitat (e.g. Stoner 2003). Additionally, the movement of this species is more constrained in this small-scale inlet than in the more extensive habitats which it commonly occupies in marine environments. This study demonstrates that queen conches can indeed accommodate those suboptimal environmental conditions over long periods of time. Most queen conch predators are considered fully marine species (Randall 1964), and the large variation in salinity in this estuarine-like habitat may prevent such predators from entering the inlet. In general, the use of lower-quality marginal habitats in order to reduce exposure to predators has been documented for large marine herbivores (green and loggerhead turtles, Heithaus et al. 2002; dugong, Wirsing et al. 2007). Ray \& Stoner (1994) noted that juvenile conches may also choose lower-quality habitat in terms of resources, compromising growth in favour of reduction of predation pressure. However, due to a lack of data on predator abundance inside and outside the inlet, more investigations are required to determine whether the absence of predators is a key factor explaining the use of the inlet by queen conches. This is of particular importance, as inlets such as Xel-Há may act as a refuge for queen conch populations threatened by overfishing, climate change and habitat degradation in their more common offshore, marine habitats (Appeldoorn 1994, Appeldoorn \& Baker 2013).
In conclusion, our study suggests that small inshore protected zones such as Xel-Há should not be discarded as a conservation option, at least from a habitat use perspective. Such groundwater-impacted inlets may provide a valuable (nursery) habitat for a considerable part of the queen conch juvenile and subadult lifespan (as indicated by the observed long periods of residence during juvenile and subadult life stages) despite environmental and topographic constraints. A network of small coastal marine protected zones encompassing this type of small-scale habitats may therefore be able to contribute to effective conservation management of this socioeconomically highly valuable species.

Acknowledgements. We thank managers and staff at Xel-Ha (www.xelha.com) for access, excellent technical support and sharing local knowledge, in particular R. Saenz, E. May, A. Chevarria, S. Perez and G. Maldonado from the section Dessarollo Sustentable. This study forms part of a larger program on queen conch ecology carried out in collaboration between Parque Xel-Ha, the Centro de Investigación y de Estudios Avanzados del Instituto Politécnico Nacional (CINVESTAV; Mexico) and the European Institute of Marine Studies (IUEM; France), instigated by D. Aldana-Aranda (CINVESTAV), L. Chauvaud (IUEM) and R. Saenz (Xel-Ha). We thank E. Amice (IUEM) for the bulk of technical support, and for the many hours he spent in the water collecting animals and servicing receivers. L. Chauvaud, J. Thebault (IUEM) and D. Aldana-Aranda, J. Peel, M. Enriquez Diaz and M. Sanchez (CINVESTAV) provided additional help with animal tagging and receiver installation. J. Peel advised on population dynamics in Xel-Ha. D. Allen and F. Smith (VEMCO) supported design of the receiver array, and F. Smith carried out the VPS computations. We thank M. Windstein for constructive discussions, and 4 anonymous reviewers and the editor R. Lipcius for their very thorough and constructive comments. This study was funded by the European Union FP7 People Program, the Europole Mer consortium, the Laboratoire des sciences de l'environnement marin (LEMAR) at IUEM and Parque Xel-Ha. T.C.S. was supported by a European Union FP7 Marie Curie International Incoming Fellowship (IIF) hosted by CNRS during this study.

\section{LITERATURE CITED}

Alós J, March D, Palmer M, Grau A, Morales-Nin B (2011) Spatial and temporal patterns in Serranus cabrilla habitat use in the NW Mediterranean revealed by acoustic telemetry. Mar Ecol Prog Ser 427:173-186

Alós J, Cabanellas-Reboredo M, Lowerre-Barbieri S (2012) Diel behaviour and habitat utilisation by the pearly razorfish during the spawning season. Mar Ecol Prog Ser 460:207-220

Appeldoorn RS (1988) Age determination, growth, mortality, and age of first reproduction in adult queen conch, Strombus gigas L. off Puerto Rico. Fish Res 6:363-378

Appeldoorn RS (1994) Queen conch management and research: status, needs and priorities. In: Appeldoorn RS, Rodriquez B (eds) Queen conch biology, fisheries and 
mariculture. Fundacion Cientifica Los Roques, Caracas, p 301-319

Appeldoorn RS, Baker N (2013) A literature review of the Queen Conch, Strombus gigas. Tech Rep. Dep Mar Sci, University of Puerto Rico, Mayaguez

Back W, Henshaw BB, Pyle TE, Plummer LN, Weidie AE (1979) Geochemical significance of groundwater discharge and carbonate solution to the formation of caleta Xel Ha, Quintana Roo, Mexico. Water Resour Res 15: 1521-1535

Berg C, Ward J, Luckhurst B, Nisbet K, Couper F (1992) Observations of breeding aggregations of the queen conch, Strombus gigas. Proc Gulf Caribb Fish Inst 42:161-171

Bissada-Gooding CE, Oxenford HA (2009) Estimating home range and density of a queen conch aggregation using acoustic telemetry and conventional tagging. Proc Gulf Caribb Fish Inst 62:383-389

Charnov EL (1976) Optimal foraging, the marginal value theorem. Theor Popul Biol 9:129-136

Christiansen F, Esteban N, Mortimer JA, Dujon AM, Hays GC (2017) Diel and seasonal patterns in activity and home range size of green turtles on their foraging grounds revealed by extended Fastloc-GPS tracking. Mar Biol 164:10

Coates JH, Hovel KA, Butler JL, Klimley AP, Morgan SG (2013) Movement and home range of pink abalone Haliotis corrugata: implication for restoration and population recovery. Mar Ecol Prog Ser 486:189-201

WDalla Rosa L, Secchi ER, Maia YG, Zerbini AN, HeideJørgensen MP (2008) Movements of satellite-monitored humpback whales on their feeding ground along the Antarctic Peninsula. Polar Biol 31:771-781

Nees ND, Hofmann M, Bahar S (2010) Physical constraint and the evolution of different foraging strategies in aquatic space. Anim Behav 79:603-611

Delgado GA, Glazer RA (2007) Interactions between translocated and native queen conch Strombus gigas: evaluating a restoration strategy. Endang Species Res 3:259-266

Doerr JC, Hill RL (2008) A preliminary analysis of habitat use, movement, and migration patterns of queen conch, Strombus gigas, in St John, USVI, using acoustic tagging techniques. Proc Gulf Caribb Fish Inst 60:509-515

Espinoza M, Farrugia TJ, Lowe CG (2011) Habitat use, movements and site fidelity of the gray smooth-hound shark (Mustelus californicus Gill 1863) in a newly restored southern California estuary. J Exp Mar Biol Ecol 401:63-74

Glazer RA, Delgado GA (2006) Designing marine fishery reserves using passive acoustic telemetry In: Taylor JC (ed) Emerging technologies for reef fisheries research and management. NOAA Prof Pap NMFS 5. NMFS, NOAA, Seattle, WA, p 26-37

Glazer RA, Delgado GA, Kidney JA (2003) Estimating queen conch (Strombus gigas) home ranges using acoustic telemetry: implications for the design of marine fishery reserves. Proc Gulf Caribb Fish Inst 14:79-89

Grüss A, Kaplan DM, Guénette S, Roberts CM, Botsford LW (2011) Consequences of adult and juvenile movement for marine protected areas. Conserv Biol 114:692-702

Heithaus MR, Frid A, Dill LM (2002) Shark-inflicted injury frequencies, escape ability, and habitat use of green and loggerhead turtles. Mar Biol 140:229-236

Heupel MR, Semmes JM, Hobday AJ (2006) Automated acoustic tracking of aquatic animals: scales, design and deployment of listening station arrays. Mar Freshw Res $57: 1-13$
Hussey NE, Kessel ST, Aarestrup K, Cooke SJ and others (2015) Aquatic animal telemetry: a panoramic window into the underwater world. Science 348:1255642

Katajisto J, Moilanen A (2006) Kernel-based home range method for data with irregular sampling intervals. Ecol Model 194:405-413

* Kramer DL, Chapman MR (1999) Implications of fish home range size and relocation for marine reserve function. Environ Biol Fishes 55:65-79

*Lauzon-Guay JS, Scheibling RE, Barbeau MA (2006) Movement patterns in the green sea urchin, Strongylocentrotus droebachiensis. J Mar Biol Assoc UK 86:167-174

Kea JSE, Humphries NE, von Brandis RG, Clarke CR, Sims DW (2016) Acoustic telemetry and network analysis reveal the space use of multiple reef predators and enhance marine protected area design. Proc R Soc Lond B Biol Sci 283:20160717, doi:10.1098/rspb.2016.0717

KLøkkeborg S, Fernö A, Jørgensen T (2002) Effect of positionfixing interval on estimated swimming speed and movement pattern of fish tracked with a stationary positioning system. Hydrobiologia 483:259-264

* McLoughlin PD, Ferguson S (2000) A hierarchical pattern of limiting factors helps explain variation in home range size. Ecoscience 7:123-130

* Medina-Gómez I, Herrera-Silveira JA (2006) Primary production dynamics in a pristine groundwater influenced coastal lagoon of the Yucatan Peninsula. Cont Shelf Res 26:971-986

Moland E, Olsen EM, Andvord K, Knutsen JA, Stenseth NC (2011) Home range of European lobster (Homarus gammarus) in a marine reserve: implications for future reserve design. Can J Fish Aquat Sci 68:1197-1210

*Peel JR, Aldana-Aranda A (2012) Growth and population assessment of the queen conch Strombus gigas (Mesogastropoda: Strombidae) by capture mark-recapture sampling in a natural protected area of the Mexican Caribbean. Rev Biol Trop 60(Suppl 1):127-137

*Perry E, Velazquez-Oliman G, Marin L (2002) The hydrogeochemistry of the Karst aquifer system of the northern Yucatan Peninsula, Mexico. Int Geol Rev 44:191-221

Phillips M, Oxenford H, Bissada C (2010) Preliminary investigation of the movements, density, and growth of juvenile queen conch in a nursery area in Barbados. Proc Gulf Caribb Fish Inst 63:428-434

R Development Core Team (2011) R: a language and environment for statistical computing. R Foundation for Statistical Computing, Vienna

Randall JE (1964) Contributions to the biology of the queen conch, Strombus gigas. Bull Mar Sci 14:246-295

* Ray M, Stoner AW (1994) Experimental analysis of growth and survivorship in a marine gastropod aggregation: balancing growth with safety in numbers. Mar Ecol Prog Ser 105:47-59

Ray M, Stoner AW (1995) Growth, survivorship, and habitat choice in a newly settled seagrass gastropod, Strombus gigas. Mar Ecol Prog Ser 123:83-94

Sandt VJ, Stoner AW (1993) Ontogenetic shift in habitat by early juvenile queen conch, Strombus gigas: patterns and potential mechanisms. Fish Bull 91:516-525

Seaman DE, Powell RA (1996) An evaluation of the accuracy of kernel density estimators for home range analysis. Ecology 77:2075-2085

Seaman DE, Millspaugh JJ, Kernohan BJ, Brundige GC, Raedeke KJ, Gitzen RA (1999) Effects of sample size on kernel home range estimates. J Wildl Manag 63:739-747 
Searle KR, Hobbs NT, Shipley LA (2005) Should I stay or should I go? Patch departure decisions by herbivores at multiple scales. Oikos 111:417-424

Seuront LA, Duponchel C, Chapperon C (2007) Heavytailed distributions in the intermittent motion behaviour of the intertidal gastropod Littorina littorea. Physica A 385:573-582

Sheel D, Bisson L (2012) Movement patterns of giant Pacific octopuses, Enteroctopus dofleini (Wülker, 1910). J Exp Mar Biol Ecol 416-417:21-31

Sims DW, Southall EJ, Humphries NE, Hays GC and others (2008) Scaling laws of marine predator search behaviour. Nature 451:1098-1102

Smith F (2013) Understanding HPE in the VEMCO Positioning System (VPS). Instruction manual. VEMCO, Bedford

Stoessell RK, Ward WC, Ford BH, Schuffert JD (1989) Water chemistry and $\mathrm{CaCO}_{3}$ dissolution in the saline part of an open-flow mixing zone, coastal Yucatan Peninsula, Mexico. Geol Soc Am Bull 101:159-169

Stoner AW (1989a) Density-dependent growth and grazing effects of juvenile queen conch Strombus gigas L. in a tropical seagrass meadow. J Exp Mar Biol Ecol 130: 119-133

Stoner AW (1989b) Winter mass migration of juvenile queen conch Strombus gigas and their influence on the benthic environment. Mar Ecol Prog Ser 56:99-104

Stoner AW (2003) What constitutes essential nursery habitat for a marine species? A case study of habitat form and function for queen conch. Mar Ecol Prog Ser 257:275-289

Stoner AW, Lally J (1994) High-density aggregation in queen conch Strombus gigas: formation, patterns, and ecological significance. Mar Ecol Prog Ser 106:73-84

Stoner AW, Sandt VJ (1992) Population structure, seasonal movements, and feeding of queen conch, Strombus gigas, in deep-water habitats of the Bahamas. Bull Mar Sci 51: $287-300$

Editorial responsibility: Romuald Lipcius, Gloucester Point, Virginia, USA
Stoner AW, Ray M, Waite J (1995) Effects of a large herbivorous gastropod on macrofauna communities in tropical seagrass meadows. Mar Ecol Prog Ser 121:125-137

Stoner AW, Mueller KW, Brown-Peterson NJ, Davis MH, Booker CJ (2012) Maturation and age in queen conch (Strombus gigas): urgent need for changes in harvest criteria. Fish Res 131-133:76-84

Wwihart RK, Slade NA, Bergstrom BJ (1988) Relating body size to the rate of home range use in mammals. Ecology 69:393-399

Turchin P (1998) Quantitative analysis of movement: measuring and modeling population redistribution in animals and plants. Sinauer Associates Incorporated, Sunderland, MA

Turner FB, Jennrich RI, Weintraub JD (1969) Home ranges and body size of lizards. Ecology 50:1076-1081

Valle-Esquivel M (1998) Growth of queen conch, Strombus gigas, in Xel-ha, Quintana Roo, Mexico. Proc Gulf Caribb Fish Inst 50:66-77

*Vander Wal E, Rodgers AR (2012) An individual-based quantitative approach for delineating areas of animal space use. Ecol Model 224:48-53

*Vannini M, Cannicci S, Mrabu E, Rorandelli R, Fratini S (2008) Random walk, zonation and the food searching strategy of Terebralia palustris (Mollusca, Potamididae) in Kenya. Estuar Coast Shelf Sci 80:529-537

Wai TC, Ng JSS, Leung KMY, Dudgeon D, Williams GA (2008) The source and fate of organic matter and the significance of detrital pathways in a tropical coastal ecosystem. Limnol Oceanogr 53:1479-1492

Wirsing AJ, Heithaus MR, Dill LM (2007) Living on the edge: Dugongs prefer to forage in microhabitats that allow escape from rather than avoidance of predators. Anim Behav 74:93-101

* Worton B (1987) A review of models of home range for animal movement. Ecol Model 38:277-298

Submitted: December 30, 2016; Accepted: March 19, 2017

Proofs received from author(s): May 5, 2017 